\title{
Seeing is Believing: Religious Media Consumption and Public Opinion toward Same-Sex Relationships
}

\author{
Samuel L. Perry* \\ University of Oklahoma \\ Landon Schnabel \\ Indiana University
}

\begin{abstract}
An extensive literature demonstrates that religion is a key determinant of Americans' social and political attitudes. This literature, however, has neglected an important measure of everyday religious practice, preference, and socialization: religious media consumption. We take a key social issue where attitudes have been shown to be largely shaped by religion-same-sex relationships - as an example to determine whether religious media consumption predicts social attitudes net of the measures typically included in the literature on religion and attitudes:

affiliation, practice, and literalism. We draw on data from three national surveys, each of which contains different measures of religious media consumption and attitudes toward various samesex relationships: the 1998 General Social Survey, 2005 Baylor Religion Survey, and 2012 Portraits of American Life Study. Both multivariate and propensity score matching analyses demonstrate that religious media consumption independently predicts lower support for same-sex relationships in all three surveys. We propose that religious media consumption is a key measure of religious practice, preference, and socialization that shapes Americans' views toward social issues through both direct messages and by fortifying subcultural boundaries.
\end{abstract}

Key Words: attitudes, public opinion, religion, media, sexuality, same-sex marriage, same-sex adoption, propensity score matching

The publisher's version of this paper can be found at DOI: 0.1177/2329496516686616

Citation: Perry, Samuel L. and Landon Schnabel. 2017. "Seeing is Believing: Religious Media Consumption and Public Opinion toward Same-Sex Relationships." Social Currents 4(5): 462481.

\footnotetext{
* Both authors contributed equally to the work, and their names are listed alphabetically. We are grateful to Brian Powell for the insightful feedback on an earlier draft. We would also like to thank the editors and three anonymous reviewers for their helpful comments. Direct correspondence to Landon Schnabel, Department of Sociology, Indiana University, 744 Ballantine Hall, 1020 E. Kirkwood Ave., Bloomington, IN 47405, USA. Email:

lpschnab@indiana.edu.
} 
An extensive literature demonstrates that religion is a key determinant of Americans' social and political attitudes. This literature, however, has neglected an important measure of everyday religious practice, preference, and socialization: religious media consumption. We take a key social issue where attitudes have been shown to be largely shaped by religion-same-sex relationships - as an example to determine whether religious media consumption predicts social attitudes net of the measures typically included in the literature on religion and attitudes: evangelical affiliation, religious practice (attendance, prayer, and scripture reading frequency), and view of the Bible.

Conservative religious identification and commitment are strongly related to public opinion toward gay and lesbian family relationships in the United States (Adamczyk and Pitt 2009; Baunach 2012; Campbell and Monson 2008; Haider-Markel and Joslyn 2008; Schnabel 2016a; Sherkat et al. 2011; Perry and Whitehead 2016). Despite extensive research on this relationship, we still know relatively little about the practical mechanisms and processes through which religious groups and subcultures shape adherents' views about same-sex relationships (Burdette, Ellison, and Hill 2005). Focusing on one potential mechanism, the current study examines the link between religious media consumption-both an indicator of and tool for socialization and boundary formation within religious subcultures (Draper and Park 2010; Park and Baker 2007; Rossman 2009; Stout and Buddenbaum 2008)—and Americans' views toward same-sex romantic and family relationships. More specifically, we consider the extent to which religious media consumption - a measure of practice, preference, and socialization in the context of everyday lived religion (Ammerman 2007, 2014; Stout and Buddenbaum 2008)—evidences a net effect on Americans' views toward same-sex relationships. To address these issues, we analyze data from three national surveys, each containing different measures of religious media 
consumption and attitudes toward various same-sex romantic and family relationships: the 1998 General Social Survey, 2005 Baylor Religion Survey, and 2012 Portraits of American Life Study. Because of concerns about self-selection — which can never be fully addressed in the context of everyday media consumption-we test our expectations using multivariate and propensity score matching techniques to better isolate an independent effect of religious media consumption on Americans' views.

\section{Background}

\section{Religion and Attitudes toward Same-Sex Relationships}

An extensive literature affirms religion's strong influence on Americans' views toward gay and lesbian family relationships and civil rights more broadly. Numerous studies demonstrate that Americans who are religiously committed—often defined in terms of religious service attendance, but occasionally including other factors like religious salience or frequency of prayer or sacred text reading - are more opposed to any type of same-sex relationship, including sexual partnerships, marriage, and adoption (Adamczyk and Pitt 2009; Baunach 2012; Campbell and Monson 2008; Haider-Markel and Joslyn 2008; Olson, Cadge, and Harrison 2006; Sherkat et al. 2011; Perry and Whitehead 2016). Additionally, research has also shown that sectarian or fundamentalist religious traditions are more opposed to same-sex relationships than are others. Illustratively, Baunach (2012) demonstrates that this link between conservative religion and opposition to same-sex marriage emerged since the 1980s following the coupling of conservative politics with religion and "family values." Subsequently, white evangelical and Black Protestants, as well as Muslims, tend to be more opposed to same-sex relationships than their counterparts, while mainline Protestants, Jews, people of other non-Christian faiths (Hindus, Buddhists), and the unaffiliated are more likely to support such relationships 
(Adamczyk and Pitt 2009; Hill, Moulton, and Burdette 200; Sherkat, Mattias de Vries, and Creek 2010; Schnabel 2016a; Sherkat et al. 2011). Catholics collectively often appear to occupy more of a middle position since they consist of both progressive, nominal groups and more traditionalist groups (Perry 2013; Putnam and Campbell 2010). Conservative theological beliefs (e.g., believing in the literalness or inerrancy of one's sacred text) are also strong predictors of negative views toward same-sex relationships and families (Perry 2015; Perry and Whitehead 2016; Powell, et al. 2010; Whitehead and Perry 2015). And while the majority of Americans now support same-sex marriage, and attitudes toward gays and lesbians are improving even among conservative Protestant groups (Schnabel 2016a), there still remains aggressive and at times even violent religious opposition to LGBT rights.

Although the influence of religious commitment and conservative traditions and beliefs on Americans' views toward same-sex relationships is well-established, relatively little work has been done to understand the social mechanisms through which religious subcultures socialize and shape adherents' views on LGBTQ issues. Early work by Wald, Owen, and Hill (1988) theorized that congregational involvement likely influenced members' views on moral and political issues through interpersonal interaction and explicit messages from the pulpit. Affirming this idea, Djupe and Gilbert (2002) showed that normative statements about homosexuality are often conveyed by clergy, and particularly those who are politically motivated. At the interpersonal level, Bean's (2015) analysis of Canadian and American evangelicals shows that American evangelical views are influenced through subtle partisan cues conveyed in corporate religious practice. And Powell and his colleagues (2010) suggest that Americans in conservative Christian communities are socialized early on to connect the biblical proscriptions against homosexual behavior with contemporary policy involving same-sex 
families. Yet socialization can be accomplished through a variety of different agents, including one's immediate family and friendship networks, school, and the media to which one is consistently exposed. In addition to socializing individuals to hold certain views, greater exposure to any of these agents is also a measure of belonging and implicit boundary-formation, thus also creating psychic pressure to adopt views consistent with one's social groups and institutions (Draper and Park 2010).

\section{Media Consumption and Public Opinion}

As media technology has continued to advance and further saturate the lives of Americans, a burgeoning literature has focused on the potential effects of exposure to particular media messages on Americans' social and political views. Research designs include lab experiments, longitudinal-panel surveys, and cross-sectional surveys: meta-analyses of this research affirm that exposure to certain messages within mainstream media has a powerful, independent effect on Americans' opinions, self-conceptions, and ultimately behaviors (Barlett, Vowels, and Saucier 2008; Grabe, Hyde, and Ward 2008). Much of the extant research focuses on the extent to which certain dominant media messages, particularly in television, may shape Americans' propensity to hold negative stereotypes of certain minority groups (Garretson 2015; Goldman 2012), their propensity to hold a negative self-image (Agliata and Tantleff-Dunn 2004; Aubrey 2006; Barlett, et al. 2008; Grabe, et al. 2008; Stice, Spangler, and Agras 2001), or their opinions about risky social behavior (Aubrey et al. 2014; Kearney and Levine 2015). A large body of research examines how secular media consumption shapes Americans' political views, but this literature has been less likely to examine religious media specifically (Barker and Knight 2000; Baumgartner and Morris 2006; Baumgartner, Morris, and Walth 2012; Hopkins and Ladd 2012; Johnston and Bartels 2010; Valentino 1999). 
As public debates regarding homosexuality have intensified over the last 20 years, studies have begun to consider the ways media consumption potentially shapes public opinion toward same-sex relationships and civil rights. Consistent with other work on positive minority portrayals and prejudice reduction, this research generally affirms that exposure to positive (explicit or implicit) messages about homosexuality is associated with more general positive affect toward sexual minorities, as well as greater support of civil rights for sexual minorities (Bonds-Raacke et al. 2007; Calzo and Ward 2009; Lee and Hicks 2011; Schiappa, Gregg, and Hewes 2006). This effect is accomplished via both the content of the media, but also through the implicit negotiation of group identities and boundaries. For example, the popular television program Will \& Grace — and more recently, Modern Family_rarely made explicit statements about tolerance for homosexuality, but watching the show allowed Americans to embrace gay men as likable and "not so different" from anyone else, and frequent viewers were more likely to relax their moral boundaries and increase tolerance toward gay men and lesbians (Bonds-Raacke et al. 2007; Schiappa et al. 2006). Conversely, consuming media that further binds individuals to in-groups that are generally intolerant of out-groups, even if no direct statements are made about those groups, might reinforce in-group moral boundaries and decrease tolerance for out-groups.

Over the past few decades, religious groups in the United States, and particularly evangelical or fundamentalist Christian groups, have increasingly risen to positions of influence within American radio, television, and cinema (Lindsay 2007) in order to utilize those media outlets as avenues for education, proselytizing, public relations, and cultural influence more broadly (e.g., Draper and Park 2010; Rossman 2009; Stout and Buddenbaum 2008; Taylor and Chatters 2011). Stout and Buddenbaum (2008) point out that religious media consumption now constitutes a particular type of religious practice, and religious media itself represents a distinct 
context for worship. And Rossman (2009) explains that while conservative Christians still tend to consume much of the same media as other Americans, Christian media often provide an opportunity to demonstrate loyalty to group values, exit or withdrawal from worldly influences, and speak out against objectionable cultural or political trends. Despite a large body of research on media consumption and public opinion, few studies have actually attempted to empirically assess the potential effects of religious media on social attitudes or behaviors. Among the exceptions, an early study by Gaddy (1984) reported that consuming religious television and radio did not influence Americans' opinions about religious organizations being active in public affairs. More recently, however, Newman and Smith (2007) found that over one quarter of Americans reported being influenced by religious media when making voting decisions in the 2000 election. After controlling for religious and political characteristics, they reported that Americans who consumed religious media were more favorable toward George W. Bush than to Al Gore and more likely than non-consumers to vote for Bush or a Republican House candidate. Although religious media consumption may be associated with more conservative political views and identifications more generally, the literature to date has neglected to assess whether these effects extend to particular social issues like same-sex relationships.

\section{Theorizing a Link between Religious Media Consumption and Public Opinion toward Same-Sex Relationships}

The research shows that people embedded within conservative religious subcultures - as evidenced by identification with sectarian or fundamentalist traditions, theological beliefs, and/or frequent religious practice - tend to oppose same-sex relationships of any kind. And while little empirical work considers the influence of distinctively religious media on public opinion, a large body of work affirms that mainstream media consumption is not only an indicator of culturally- 
determined tastes, but is also a tool for socialization and boundary formation, and thus evinces robust effects on Americans' attitudes toward particular social issues and groups. Therefore, we generally expect that more frequent consumption of religious media, net of other religious and socio-demographic characteristics, will negatively influence Americans' views toward same-sex relationships.

This broad effect, however, may be contingent on several factors, specifically the content of the religious media and the nature of consumers' participation. Because previous research does not provide specific insights on these issues to generate hypotheses, we explore them as research questions. First, the content of the religious media should be important. On the one hand, certain religious media outlets (e.g., evangelical radio programs or Focus on the Family books) may make direct statements about homosexuality, recounting biblical proscriptions against it, identifying "the gay agenda" as a growing cultural and political threat, or demonizing it along with other factors identified as part of a "secular agenda" (Gilgoff 2008; Goldberg 2006). More frequent consumption of such material in the form of books or radio programs could potentially influence consumers' views on same-sex relationships more strongly than religious media where no direct messages about homosexuality are conveyed. Yet, consumption of religious media that does not directly mention homosexuality (e.g., watching Touched by an Angel) could still indicate, and serve to further, embeddedness within a religious subculture (e.g., evangelical Protestantism) that prefers religious to secular media and uses sexuality to draw boundaries between themselves and the outside world (Schnabel 2016a; Tranby and Zulkowski 2012). Rather than such consumption causing more negative attitudes, it could be an effective proxy for subcultural tastes and preferences that have been neglected in past research. 
Second, the influence of any media on social attitudes may differ by whether the consumer is participating actively (e.g., reading a book or newspaper) or passively (e.g., watching television or listening to a radio show). While research shows passive forms of media consumption also influence consumers' attitudes (e.g., Baumgartner and Morris 2006; Baumgartner, et al. 2012; Bonds-Raacke et al. 2007; Schiappa et al. 2006), it may be that more active forms of media consumption require more direct attention and thus potentially convey homophobic messages more effectively.

\section{Data, Measures, and Methods}

\section{Data}

We use the 2005 Baylor Religion Survey (BRS; $N=1,278$ ), the 2012 Portraits of American Life Study (PALS; $N=1,163)$, and the 1998 General Social Survey (GSS; $N=613$ ) because they have different strengths that allow us to test the robustness of the pattern across different types of measures and across time periods, as well as to address limitations for each individual dataset. The BRS has more outcome measures than the other surveys, the measures of religious media consumption are more specific and concrete, and demographic results from the 2005 BRS compare favorably to demographic results from other national surveys, despite some concerns about its representativeness (Bader, Mencken, and Froese 2007; Sherkat 2010; Smith and Kim 2007). The 2012 PALS provides more recent data, but one outcome measure and the religious media measures are less specific than the BRS measures. Finally, the 1998 GSS provides what many consider to be particularly high-quality data, but the relevant media measure is older and provides a smaller sample due to the use of different survey forms that are given to random subsamples of the respondents. By using all three data sources we are able to triangulate the results across three samples, a variety of religious media consumption measures, and a period 
of 14 years - during which public opinion toward same-sex relationships was rapidly changingto examine the robustness, breadth, and continuity of the results. ${ }^{1}$

Missing data are handled with listwise deletion and we do not use survey weights. Sensitivity analyses using multiple imputation and/or weights yielded substantively equivalent results.

\section{Measures}

Dependent Variables. The outcomes are binary measures of support for same-sex relationships. The BRS contains measures of support for same-sex marriage, same-sex adoption, and the perceived morality of homosexuality. PALS contains a measure of support for same-sex marriage, and the GSS includes a measure about the perceived morality of homosexuality. ${ }^{2} \mathrm{We}$ use binary measures of support to take response patterns into account (based on preliminary multinomial logistic regression analyses), to make the effects across data sets more comparable, to make substantive differences clearer using predicted probabilities, and, most importantly, because the general patterns are the same regardless of specification. ${ }^{3}$ Table 1 includes the

\footnotetext{
${ }^{1}$ Using three surveys that include different predictor and outcome measures and that were fielded at different times on different samples makes the narrative more complex, and thus less clear. Nevertheless, we consider it important to hold the potential relationship between religious media consumption and attitudes to a high standard of robustness and continuity before making an argument for its more regular inclusion in attitudinal research. If similar patterns hold across samples, time, estimation strategies, and predictor and outcome measures, it would suggest a strong, important, and likely ongoing relationship between religious media consumption and attitudes that warrants additional attention.

${ }^{2}$ Although it would be ideal to have all three measures in all three surveys to better test whether the patterns vary by different types of similar attitudes, high correlations and equivalent patterns across the three outcomes in the BRS suggests that each measure, including the individual measures available in the PALS and GSS, tap into similar general sentiments about same-sex relationships. These sentiments apply not only to beliefs about one measure but cut across beliefs about same-sex marriage, adoption, and sex and patterns for one measure could be expected to be similar to effects on another.

${ }^{3}$ Sensitivity analyses demonstrate that our estimates are slightly more conservative because we use a binary outcome. See online supplement and Schnabel and Sevell (Forthcoming) for a further justification for where the measures are split to create the binary outcomes.
} 
wording of the dependent variables and the religious media consumption variables, and Table 2 presents metrics and mean scores for these measures.

\section{[TABLES 1 AND 2 ABOUT HERE]}

Religious Media Consumption Measures. Consumption of religious media is the key predictor. Although we would like to provide a more specific definition of religious media, due to the data that are available we of necessity adopt the rather expansive notion of "religious media" used by the researchers who collected the GSS, BRS, and PALS data we use. ${ }^{4}$ Like religious service attendance, religious media consumption can mean different things and have different effects across different social and cultural contexts (Stout and Buddenbaum 2008). For example, we might expect different outcomes based on frequently attending a Unitarian Universalist congregation versus a Southern Baptist congregation or frequently reading liberation theology versus reading Focus on the Family materials. However, we anticipate that religious media consumption, like attendance, will have a generally conservatizing effect because most religious media, like most congregations that people attend, are not in support of same-sex relationships. Therefore, we contend that religious media consumption, like attendance, is a meaningful measure of religious practice that could consistently shape attitudes.

The BRS includes measures for whether the respondent has read three different evangelical Christian books (The Purpose Driven Life, a book from the Left Behind series, and a James Dobson book), as well as measures of whether the respondent had ever watched two Christian-themed shows broadcast on mainstream television stations $\left(7^{\text {th }}\right.$ Heaven and Touched by

\footnotetext{
${ }^{4}$ Because of how the questions are fielded, sometimes "religious media" are specific books or television shows that were particularly relevant at the time a survey was fielded, and sometimes "religious media" is an amorphous concept that includes whatever respondents consider "religious television" when asked how much time they spend watching religious television.
} 
an Angel). ${ }^{5}$ PALS includes measures of how frequently the respondent had read religious periodicals or books in the previous year, as well as how frequently they had visited religious websites or online groups. Finally, the GSS includes a measure of time spent watching religious television. The BRS measures are clearly Christian media, but the PALS and GSS variables refer to "religious media" more generally. Nevertheless, the relatively greater supply of conservative Christian media than other forms of religious media in the U.S. suggest that "religious media" is, more often than not, conservative Protestant. Put simply, sectarian subcultural groups are simply more driven to create their own media as an alternative to mainstream media, and Christianity is America's dominant religion and conservative Protestantism the dominant sectarian subculture. ${ }^{6}$ Cross tabulations of religious media consumption by religious categories (Steensland et al. 2000) confirm this point, demonstrating that "religious" media is consumed most often by Christians, and especially evangelical Protestants. ${ }^{7}$ Most Jews rarely consumed religious media, and those in non-Christian faiths and those with no religious affiliation were also very unlikely to consume religious media. Interactions of affiliation and religious media consumption in the regression

\footnotetext{
${ }^{5}$ While we recognize that these are different types of religious media consumption, each has been included in previous research on religious media and its connection to religious experience (Ammerman 2007; Mullikin 2006; Stout and Buddenbaum 2008). Moreover, we use each type because we theorized that subcultural religious media would yield larger associations and we want to test whether the findings confirm or lead us to revise our theory. We expect that in the case of $7^{\text {th }}$ Heaven and Touched, Christian-preferred mainstream television, that choosing to not consume these shows (and possibly selecting mainstream alternatives that are less Christian-preferred in the media market, such as Will \& Grace) is possibly a more important cultural signifier than choosing to consume them. ${ }^{6}$ Although most religious media produced and consumed in the U.S. is conservative Protestant or at least Christian, the constraint of media supply on what "religious media" means could vary by medium. For example, 2012 PALS respondents could conceivably have accessed almost any type of "religious" website, but 1998 GSS respondents did not have as wide a range of televised religious media available to them. Consequently, the meaning of "religious media" is context and medium specific based on what media are available.

${ }^{7}$ It is possible that our media consumption measure distinguishes between conservative and liberal Protestants in ways that the Steensland et al. (2000) schema does not. Due to the diversity of individual Protestants and the congregations they worship in, it is likely that some people who on other measures, such as religious media consumption, are more like conservative Protestants get categorized with liberal Protestants and that people who have beliefs and values similar to liberal Protestants get categorized with conservative Protestants. These distinctions highlight the importance of including multiple religion measures because there is not a uniform "religion" that lies along a single scale from no religion to complete religion, there are specific religions with distinct characteristics and divergent social effects.
} 
analyses demonstrate that the primary effects are for Christian religious groups, with some divergent effects for the few non-Christians who indicated that they consumed religious media. ${ }^{8}$

We first consider ordinal measures of religious consumption and then binary treatments for heavy religious media engagement. Table 2 presents metrics and descriptive statistics for these key independent variables, and the binary treatments of the media variables used in the second part of our analyses are defined in Table 3.

Controls. Of primary concern is the issue of self-selection-namely, that any negative relationship observed between religious media consumption and support for same-sex relationships would simply be due to the fact that Americans who consume religious media are already more likely to oppose same-sex relationships in the first place. In multivariate models, we seek to mitigate this possibility by controlling for the respondents' religious commitment (measured in terms of practice), religious affiliation, and theological beliefs. Across surveys, we measure religious commitment with an index that includes respondents' frequency of religious service attendance, prayer, and scripture reading. This index allows for a more comprehensive measure of religious commitment beyond what can be provided by using religious service attendance alone (Perry 2015). We measure affiliation with a binary variable for whether a respondent is evangelical or not, following the Steensland et al. (2000) religious categorization scheme. ${ }^{9}$ Finally, we measure theological beliefs with questions asking about respondents' views of the Bible. We use a series of dummies for the provided response options, which vary somewhat for each survey (see Table 2 for more information). We also control for the same key

\footnotetext{
${ }^{8}$ Therefore, whatever broad patterns we find will be most relevant to the U.S. context, which is majority Christian and has an exceptionally high number of evangelical Protestants in comparison to many similarly industrialized countries.

${ }^{9}$ Sensitivity analyses with all seven categories included, some of which are quite small and thus problematic for the propensity score matching analyses, yield substantively equivalent results in the regression analyses.
} 
socio-demographic characteristics across surveys (see table notes for the measures included in the models). ${ }^{10}$ These controls cannot fully address issues of self-selection, but they will allow us to demonstrate whether there is an association between religious media consumption and attitudes net of key religious measures and sociodemographic characteristics.

\section{Analytic Strategy}

Most broadly, our study is interested in whether religious media consumption has an independent relationship with Americans' attitudes toward same-sex relationships. Our use of three different data sets with different measures of both religious media and same-sex relationships allows us to further parse these findings. Our analyses employ both multivariate logistic regression models with post-estimation predicted probabilities and propensity score matching.

Propensity score matching (PSM) is not new, but is still used infrequently by sociologists (Rosenbaum and Rubin 1983; Wildeman 2010). PSM allows social scientists to create a pseudoexperiment when an experiment would be impossible in real world conditions. For our study, this is done by matching respondents in the sample based on the predicted probability they would regularly consume religious media_-based upon measures of religious practice, affiliation, and belief, as well as key socio-demographic characteristics (i.e., the propensity score) — as a nonparametric feature of these pre-treatment (or predetermined) observed characteristics (Dehejia and Wahba 2002; Williams et al. 2011). In other words, we compare matched treated and control subjects who are as similar as possible, controlling for the existence of confounding factors that would make people more likely to be in the treatment group (i.e., more likely to regularly

\footnotetext{
${ }^{10} \mathrm{We}$ conducted correlation and collinearity diagnostics and our zero-order correlations (see appendix for focal variable correlations), VIF, and tolerance levels are acceptable for focal variables and socio-demographic controls.
} 
consume religious media) (Becker and Ichino 2002). The PSM models thus estimate the average effect of regularly consuming religious media among respondents similarly likely to engage in such behavior.

Following the order of our questions, in the first stage of the analysis we present predicted probabilities of support for same-sex relationships by media consumption based on multivariate logistic regression models (see online supplement for regression coefficients) with controls held at local means in post-estimation (Figures 1-4). In the second stage (Table 3), we use propensity score matching models to test the relationship between regular media consumption and support for same-sex relationships across the three surveys. ${ }^{11}$

\section{Results}

\section{Predicted Probabilities}

We start by presenting results that describe the observed relationship between religious media consumption and attitudes toward same-sex relationships. There is a strong and clear bivariate correlation between all of our media predictors and each outcome $(\mathrm{p}<.001$; see appendix for correlation matrices). In fact, these correlations are on par with the magnitude of correlations for other religion measures known to affect attitudes toward same-sex relationships, including common measures of belonging (affiliation), behaving (religious practice), and believing (view of the Bible). But what is the substantive magnitude of this relationship? And does it operate net of other key religion measures, or is it just a spurious correlation that is explained by other measures of belonging, behavior, and believing?

\footnotetext{
${ }^{11}$ Post-estimation predicted probabilities are calculated and difference tests conducted using SPOST13 functions provided by Long and Freese (2014), and propensity score matching is implemented using Stata-provided functions in Stata 13.
} 
Figures 1 through 4 show predicted probabilities based upon the logistic regression models we present in the online supplement. ${ }^{12}$ Controls were held at local means for postestimation calculations to arrive at these predicted probabilities (see Schnabel 2016b on the utility of this approach). These figures provide a big-picture overview and make it clear that people who consume more religious media are more likely to hold negative views of same-sex relationships. Across measures and data sets, consuming more religious media is associated with more opposition to same-sex relationships, and those who consume the most are the most opposed. For example, Figure 1 shows that people who had read none of the three books were predicted to be approximately 52 times more likely to support same-sex marriage than those who had read all three.

\section{[FIGURES 1-4 ABOUT HERE]}

The multivariate models (see online supplement) on which the predicted probabilities were based demonstrate that, in all three surveys, religious media consumption functions net of other measures of religiosity and religious belief that are commonly examined in studies of the effect of religion on public opinion. ${ }^{13}$ In the online supplement, we also demonstrate that an additional measure from the 1996 and 1998 General Social Surveys, which asks whether the respondent had watched or listened to a religious program in the last week, also provides similar

\footnotetext{
${ }^{12}$ The categories we use are the same as in the values in the data except for the GSS religious TV time variable for which we created categories out of a continuous variable. Sensitivity analyses demonstrated that the predicted probabilities are almost identical whether the media measures are treated as ordinal in the models (as presented in the paper and in the online supplement) or as a series of binaries.

${ }^{13}$ We present ordinal media measures because these models were the basis of the predicted probabilities we present. Sensitivity analyses with binary media measures for heavy consumption provide similar results in the same multivariate models. We also tested how much of the effects of the other religion measures were explained by religious media consumption using the KHB method to ensure that religious media consumption was not just a pathway by which the other measures mattered (and that each of the religious measures do have separate effects so that each is important). We found that although media consumption sometimes mediates a small proportion of the effect of religious practice (typically around 20\%), it does not mediate the effects of evangelical affiliation or of one's view of the Bible. Notably, measures of religious media consumption and the typical measures of religious belonging, behaving, and believing all have significant effects on attitudes when in the same model, and thus each are important independent factors to consider in attitudinal research.
} 
results (it was not included in the main text due to sample issues discussed in the online supplement). ${ }^{14}$

\section{Propensity Score Matching}

The foregoing results demonstrated a clear relationship between religious media consumption and opposition to same-sex relationships. But even though we found a persistent relationship when controlling for religious factors strongly correlated with religious media consumption (see correlation matrices in the appendix), we still do not know what the effects of regularly consuming religious media could really be expected to be for people equally likely to regularly consume religious media. In other words, is there really an independent relationship between religious media consumption and attitudes toward same-sex relationships, or is the association simply a function of interrelationships between religious media consumption and other measures of religious belonging, behaving, and believing? To put this clearly strong association to the test, we conduct propensity score matching analyses using binary treatments of regular religious media consumption. This pseudo-experimental method will provide the effect of receiving the treatment, correcting for selection bias by matching respondents who are equally likely to engage in this behavior who do and who do not regularly consume religious media.

Table 3 provides the estimated average treatment effects from propensity score models based on all three surveys. These coefficients represent the estimated effect of being in the

\footnotetext{
${ }^{14}$ In sensitivity analyses, we considered interaction effects between media consumption and evangelical identity. Although there were no interaction effects between religious media consumption and evangelical identity in the 1998 GSS data, there were interaction effects in the 2005 BRS data and the 2012 PALS data. In the BRS data, evangelicals who read more books were particularly opposed to same-sex relationships, whereas watching the shows actually had a smaller effect on evangelicals than other groups (possibly because, for sectarian evangelicals, $7^{\text {th }}$ Heaven and Touch by an Angel may represent somewhat mainstream media consumption). In the PALS data, religious reading had a larger effect and religious websites had a marginally $(p<.1)$ larger effect on evangelical opposition to same-sex relationships. Therefore, in more recent years, religious media, especially more sectarian religious media, has had a larger effect on evangelical opposition to same-sex relationships than on the views of other groups.
} 
treatment group when compared to people equally likely to be selected into it. All coefficients are negative, though not all are significant. First considering the BRS analyses, we see that having read all three books-The Purpose Driven Life, a Left Behind Series book, and a book by James Dobson, which are subcultural Christian media—-has a large and consistently significant $(\mathrm{p}<.001)$ effect across attitudes toward same-sex marriage, adoption, and sex. Having watched both shows $-7^{\text {th }}$ Heaven and Touched By an Angel, which are Christian-preferred mainstream media-demonstrates much smaller effects, which are only significant $(p<.05)$ on views of sex and marginally significant $(p<.1)$ on views of marriage.

\section{[TABLE 3 ABOUT HERE]}

With the newer PALS data, we find that regularly visiting religious websites has a stronger negative effect on the attitudes of people similarly likely to engage in this behavior, but reading, at least as it is measured here, does not. Therefore, the internet may now be a more important medium for religious socialization, at least as it relates to public opinion. Finally, the GSS analyses demonstrate that this pattern is not new and extends back at least to 1998:

watching religious TV at least two hours a week had a strong negative effect on attitudes toward the morality of homosexuality, similar to the effects of TV on views of homosexuality in the BRS analyses. ${ }^{15}$

Across time periods and samples we see that religious media consumption has a consistent negative relationship with acceptance of same-sex relationships. The notable effects of specific evangelical reading materials in the BRS suggests that more distinctly subcultural media has a stronger effect than mainstream media that Christians happen to enjoy, and that measures that ask about specific rather than general religious media consumption may be more efficient

\footnotetext{
${ }^{15}$ See online supplement for an additional GSS measure of religious media consumption.
} 
predictors of attitudes. Nevertheless, we also found a relationship for more general measures of religious media consumption, which suggests that survey items that are less context-specific are also good predictors of social attitudes. This is likely because "religious" media tends to be more of a conservative Christian variety (which is why it is primarily consumed by evangelicals) and thus the ambiguous term "religious" is likely serving as a proxy for this sort of media. Despite the apparent generalizability and consistency of our patterns in the U.S., change over time seems to be important and, more recently, visiting religious websites is particularly important as demonstrated by its strong effect on people equally likely to engage in this behavior.

\section{Discussion and Conclusions}

Using data from three national surveys and employing both multivariate and propensity score matching techniques, we demonstrated that various types of religious media consumption are strongly associated with Americans' support for same-sex relationships. Our propensity score matching analyses suggest that the religious media consumption has an effect on attitudes toward same-sex relationships net of sociographic and ideological characteristics, and, more importantly, other measures of religion known to have a large impact on these attitudes.

Although findings from all three surveys demonstrate that religious media consumption in general has an independent effect on public opinion toward same-sex relationships, the results from different types of religious media with different content allow us to parse these findings to some extent. In one survey, religious reading was predictive of negative attitudes toward all same-sex relationships (2005 BRS), while in another survey it was unrelated (2012 PALS). This difference is likely because the material read in the 2005 BRS was explicitly evangelical Christian, whereas the PALS question only asked about "religious" material in general. Although we do not think that same-sex attitudes are necessarily the result of direct statements about 
homosexuality found in the evangelical books listed (though James Dobson is consistent and explicit in his opposition to same-sex relationships), it is likely that greater exposure to these evangelical books are a proxy for engagement in other forms of evangelical media consumption, which further entrenches consumers within a broader evangelical subculture that largely opposes same-sex relationships. Interestingly, we also find a strong effect of "religious" TV watching on support for homosexuality (1998 GSS), which also seems to include watching religion-themed shows broadcast on mainstream television networks (2005 BRS). This pattern further supports the idea that direct messages about homosexuality in religious media may not be as important as the connection to a broader subculture that opposes same-sex relationships on moral grounds. Moreover, the fact that our findings held across three data sets spanning 14 years, during a time when Americans' attitudes toward same-sex relationships were changing rapidly, indicates that the effect of religious media consumption is remarkably consistent.

This study's findings contribute to the research on religion and American public opinion by highlighting a potential mechanism through which religious subcultures influence the public's attitudes. The consumption of religious media is not only an indicator of socially-informed cultural tastes, but it also serves to socialize and embed adherents within a community and inform the consumers' opinions. Consumers of religious media are likely directly influenced by explicit messages about social issues while also being more indirectly influenced by embededness in a religious subculture that defines itself via moral boundaries (Schnabel 2016a; Tranby and Zulkowski 2012). Future research could leverage qualitative interviews and experimental designs to further isolate the specific processes connecting religious media consumption with respondents' social and political attitudes. Moreover, because we observed the strongest associations between subcultural Christian media and attitudes toward homosexuality, 
and because even "religious" media is likely serving as a proxy for conservative Christian media, future survey items could be more explicit and ask respondents about how often they consume content from "Christian" radio, TV, reading materials, or websites. This approach would provide greater specificity, without asking about particular programs that are no longer on the air or popular, even among Christians. Moreover, asking about "Christian” media content would allow researchers to use (and compare results from) survey items outside of one geographical and temporal context.

Unfortunately, the data from all three surveys analyzed in this study are cross-sectional, and thus we cannot establish temporal precedence with certainty. Yet there are good reasons to argue for the independent effect of religious media consumption on Americans' attitudes toward same-sex relationships. The alternative theory would not be reverse causation (it is unlikely that Americans' opposition to same-sex relationships would be the only reason they consume religious media), but that of self-selection: people who consume religious media would already be the sort of people who oppose same-sex relationships. Previous experimental work on a variety of other media types and attitudinal outcomes has repeatedly affirmed that media exposure shapes attitudes, and is not merely a result of self-selection into specific messages. The literature would benefit from future research that would allow researchers to further control for the possibility of self-selection and isolate the independent effect of religious media consumption on Americans' social and political views. Additional forms of everyday religion practiced and experienced via media, such as social media posts and feeds, could shed further light on the formation and reinforcement of beliefs and attitudes. Another unfortunate limitation of our data is that none of the data sets had a sufficient number of non-Christians to conduct meaningful 
subsample analyses. Future research would ideally be able to assess whether "religious" media consumption has the same conservatizing effect for non-Christians as for Christians.

Moving beyond the specific case of attitudes toward same-sex relationships, this study suggests that religious media consumption is a key religion measure that should be included in future research on public opinion and other topics. Religious media consumption encompasses religious practice, preference, and socialization, all in the context of everyday lived religion (Ammerman 2007, 2014; Stout and Buddenbaum 2008). It is a measure of people's religious experience when they may not think they are doing something religious. Even though it happens in what we might think of as the "secular" portion of people's lives, choosing to consume certain types of media is no less a religious practice than attending religious services and appears to have a closer relationship with some sociopolitical attitudes.

Given the strength of religion in America, and its potential for shaping the public's beliefs and values, research should continue to examine the relationship between religion and attitudes. We argue that such research should consider not just affiliation, literalism, and typical practice measures, but also religious media consumption, which we argue is a key measure of the lived everyday religion of many Americans. We demonstrated that religious media mattered in 1998, in 2005, and in 2012, but as some religious conservatives in the United States continue to feel more marginalized because of their traditionalist views on issues like homosexuality, it is possible that the role of religious media as a means of developing and fortifying subcultural boundaries will become even more pronounced. 
Religious Media and Same-Sex Relationships

\section{APPENDIX}

[TABLES A1-A3 ABOUT HERE] 


\section{REFERENCES}

Adamczyk, Amy and Cassady Pitt. 2009. "Shaping Attitudes about Homosexuality: The Role of Religion and Cultural Context.” Social Science Research 38(2):338-51.

Agliata, Daniel, and Stacey Tantleff-Dunn. 2004. "The Impact of Media Exposure on Males' Body Image.” Journal of Social and Clinical Psychology 23(1):7-22.

Ammerman, Nancy T. 2007. Everyday Religion: Observing Modern Religious Lives. New York: Oxford University Press.

Ammerman, Nancy T. 2014. Sacred Stories, Spiritual Tribes: Finding Religion in Everyday Life. New York: Oxford University Press.

Aubrey, Jennifer Stevens. 2006. "Exposure to Sexually Objectifying Media and Body SelfPerceptions among College Women: An Examination of the Selective Exposure Hypothesis and the Role of Moderating Variables.” Sex Roles 55:159-172.

Aubrey, Jennifer Stevens, Elizabeth Behm-Morawitz, and Kyungbo Kim. 2014. 'Understanding the Effects of MTV's and Pregnant on Adolescent Girls' Beliefs, Attitudes, and Behavioral Intentions toward Teen Pregnancy." Journal of Health Communication 19:1145-1160.

Bader, Christopher D., F. Carson Mencken, and Paul Froese. 2007. “American Piety 2005: Content and Methods of the Baylor Religion Survey." Journal for the Scientific Study of Religion 46(4):447-63.

Barker, David, and Kathleen Knight. 2000. "Political Talk Radio and Public Opinion.” Public Opinion Quarterly 64:149-170. 
Barlett, Christopher, Christopher Vowels, and Donald A. Saucier. 2008. "Meta-analyses of the Effects of Media Images on Men's Body-Image Concerns.” Journal of Social and Clinical Psychology 27(3):279-310.

Baumgartner, Jody, and Jonathan S. Morris. 2006. "The Daily Show Effect: Candidate Evaluations, Efficacy, and American Youth.” American Politics Research 34(3):341-367. Baumgartner, Jody, Jonathan S. Morris., and Natasha L. Walth. 2012. "The Fey Effect: Young Adults, Political Humor, and Perceptions of Sarah Palin in the 2008 Presidential Election Campaign.” Public Opinion Quarterly 76(1):95-104.

Baunach, Dawn M. 2012. “Changing Same-Sex Marriage Attitudes in America From 1988 Through 2010." Public Opinion Quarterly 76:364-78.

Becker, Sascha O., and Andrea Ichino. 2002. "Estimation of Average Treatment Effects Based on Propensity Scores.” Stata Journal 2(4):358-377.

Bonds-Raacke, Jennifer M., Elizabeth T. Cady, Rebecca Schlegel, Richard J. Harris, and Lindsay Firebaugh. 2007. "Remembering Gay/Lesbian Media Characters: Can Ellen and Will Improve Attitudes toward Homosexuals?” Journal of Homosexuality 53(3):19-34.

Burdette, Amy, Christopher Ellison, Terrence Hill. 2005. “Conservative Protestantism and Tolerance toward Homosexuals: An Examination of Potential Mechanisms.” Sociological Inquiry 75:177-96.

Calzo, Jerel P., and L. Monique Ward. 2009. “Media Exposure and Viewers' Attitudes toward Homosexuality: Evidence for Mainstream or Resonance?” Journal of Broadcasting \& Electronic Media 53(2):280-299.

Campbell, David E., and J. Quin Monson 2008. “The Religion Card: Gay Marriage and the 2004 Presidential Election.” Public Opinion Quarterly 72:399-419. 
Dehejia, Rajeev H., and Sadek Wahba. 2002. "Propensity Score Matching Methods for NonExperimental Causal Studies.” Review of Economics and Statistics 84(1):151-61.

Djupe, Paul A., and Christopher P. Gilbert. 2002. "The Political Voice of Clergy." The Journal of Politics 64(2):596-609.

Draper, Scott, and Jerry Z. Park. 2010. "Sunday Celluloid: Visual Media and Protestant Boundaries with Secular Culture.” Sociological Spectrum 30:433-458.

Gaddy, Gary D. 1984. "The Power of Religious Media: Religious Broadcast Use and the Role of Religious Organizations in Public Affairs.” Review of Religious Research 25(4):289-302.

Garretson, Jeremiah J. 2015. “Does Change in Minority and Women’s Representation on Television Matter? A 30-Year Study of Television Portrayals and Social Tolerance.” Politics, Groups, and Identities DOI:10.1080/21565503.2015.1050405

Gilgoff, Dan. 2008. The Jesus Machine: How James Dobson, Focus on the Family, and Evangelical America are Winning the Culture War. New York: St. Martin's.

Goldberg, Michelle. 2006. Kingdom Coming: The Rise of Christian Nationalism. New York: Norton.

Goldman, Seth K. 2012. "Effects of the 2008 Obama Presidential Campaign on White Racial Prejudice.” Public Opinion Quarterly 76(4):663-687.

Grabe, Shelly, Janet Shibley Hyde, and L. Monique Ward. 2008. "The Role of the Media in Body Image Concerns among Women: A Meta-Analysis of Experimental and Correlational Studies.” Psychological Bulletin 134(3):460-476.

Haider-Markel, Donald P., and Mark R. Joslyn. 2008. "Beliefs about the Origins of Homosexuality and Support for Gay Rights: An Empirical Test of Attribution Theory." Public Opinion Quarterly 72(2):291-310. 
Hill, Terrence D., Benjamin E. Moulton, and Amy M. Burdette. 2004. “Conservative Protestantism and Attitudes toward Homosexuality: Does Political Orientation Mediate This Relationship?" Sociological Focus 37:59-70.

Hopkins, Daniel J., and Jonathan M. Ladd. 2012. "The Reinforcing Effects of Fox News." http://people.iq.harvard.edu/ dhopkins/FoxPersuasion021212.pdf. Downloaded on August 1, 2015.

Johnston, Christopher D., and Brandon L. Bartels. 2010. "Sensationalism and Sobriety: Differential Media Exposure and Attitudes toward American Courts.” Public Opinion Quarterly 74:260-285.

Kearney, Melissa S., and Phillip B. Levine. 2015. Media Influences on Social Outcomes: The Impact of MTV's 16 and Pregnant on Teen Childbearing. The American Economic Review (forthcoming).

Lee, Tien-Tsung, and Gary R. Hicks. 2011. "An Analysis of Factors Affecting Attitudes toward Same-Sex Marriage: Do the Media Matter?" Journal of Homosexuality 58:1391-1408.

Lindsay, D. Michael. 2007. Faith in the Halls of Power: How Evangelicals Joined the American Elite. New York: Oxford University Press.

Long, J. Scott, and Jeremy Freese. 2014. Regression Models for Categorical Dependent Variables Using Stata. $3^{\text {rd }}$ Edition. College Station, TX: Stata Press.

Mullikin, Peggy Lynn. 2006. "Religious and Spiritual Identity: The Impact of Gender, Family, Peers and Media Communication in Post-Adolescence." Journal of Communication \& Religion 29(1):178-203.

Newman, Brian, and Mark Caleb Smith. 2007. "Fanning the Flames: Religious Media Consumption and American Politics." American Politics Research 35(6):846-877. 
Olson, Laura R., Wendy Cadge, and James T. Harrison. 2006. "Religion and Public Opinion about Same-Sex Marriage.” Social Science Quarterly 87:340-60.

Park, Jerry Z., and Joseph Baker. 2007. "What Would Jesus Buy: American Consumption of Religious and Spiritual Material Goods.” Journal for the Scientific Study of Religion 46(4):501-517.

Perry, Samuel L. 2013. "Multiracial Church Attendance and Support for Same-Sex Romantic and Family Relationships.” Sociological Inquiry 83:259-85.

Perry, Samuel L. 2015. "Bible Beliefs, Conservative Religious Identity, and Same-Sex Marriage Support: Examining Main and Moderating Effects." Journal for the Scientific Study of Religion 54(4):792-813.

Perry, Samuel L., and Andrew L. Whitehead. 2016. "Religion and Non-traditional Families in the United States." Sociology Compass 10(4):391-403.

Powell, Brian, Catherine Bolzendahl, Claudia Geist, and Lala Steelman 2010. Counted out: Same-sex relations and Americans'definitions of family. New York: Russell Sage.

Putnam, Robert E., and David E. Campbell. 2010. American Grace: How Religion Divides and Unites Us. New York: Simon \& Schuster.

Rosenbaum, P. R., and D. B. Rubin. 1983. "The Central Role of the Propensity Score in Observational Studies for Causal Effects.” Biometrika 70(1):41-55.

Rossman, Gabriel. 2009. "Hollywood and Jerusalem: Christian Conservatives and the Media." Pp. 304-328 in Evangelicals and Democracy in America, Vol. 1: Religion and Society, edited by Steven Brint and Jean Reith Schroedel. Thousand Oaks, CA: Russell Sage. 
Schiappa, Edward, Peter G. Gregg, Dean E. Hewes. 2006. “Can One TV Show Make a Difference? Will \& Grace and the Parasocial Contact Hypothesis.” Journal of Homosexuality 51(4):15-37.

Schnabel, Landon. 2016a. "Gender and Homosexuality Attitudes across American Religious Groups from the 1970s to 2014: Similarity, Distinction, and Adaptation.” Social Science Research 55(1):31-47.

Schnabel, Landon. 2016b. "The Gender Pray Gap: Wage Labor and the Religiosity of HighEarning Women and Men." Gender \& Society 30(4):643-669.

Schnabel, Landon and Eric Sevell. Forthcoming. "Should Mary and Jane Be Legal? Americans' Attitudes toward Marijuana and Same-Sex Marriage Legalization, 1988-2014.” Public Opinion Quarterly.

Sherkat, Darren E. 2010. "Review of What Americans Really Believe: Findings from the Baylor Surveys of Religion.” Journal for the Scientific Study of Religion 49(1):194-96.

Sherkat, Darren E., Kylan Mattias de Vries, and Stacia Creek. 2010. "Race, Religion, and Opposition to Same-Sex Marriage.” Social Science Quarterly 91(1):80-98.

Sherkat, Darren E., Melissa Powell-Williams, Gregory Maddox, and Kylan Mattias de Vries. 2011. "Religion, Politics, and Support for Same-Sex Marriage in The United States, 1988-2008.” Social Science Research 40:167-180.

Smith, Tom W., and Seokho Kim. 2007. "Counting Religious Nones and Other Religious Measurement Issues: A Comparison of the Baylor Religion Survey and General Social Survey." GSS Methodological Report 110(1):1-15. 
Steensland, Brian, Jerry Z. Park, Mark D. Regnerus, Lynn D. Robinson, W. Bradford Wilcox, and Robert D. Woodberry. 2000. "The Measure of American Religion: Toward Improving the State of the Art." Social Forces 79(1):291-318.

Stice, Eric, Diane Spangler, and W. Stewart Agras. 2001. "Exposure to Media-Portrayed ThinIdeal Images Adversely Affects Vulnerable Girls: A Longitudinal Experiment.” Journal of Social and Clinical Psychology 20(3):270-88.

Stout, Daniel A., and Judith M. Buddenbaum. 2008. "Approaches to the Study of Media and Religion: Notes from the Editors of the Journal of Media and Religion with Recommendations for Future Research.” Religion 38(3):226-232.

Taylor, Robert Joseph, and Linda M. Chatters. 2011. "Religious Media Use Among American Americans, Black Caribbeans, and Non-Hispanic Whites.” Journal of African American Studies 15:433-454.

Tranby, Eric and Samantha E. Zulkowski. 2012. "Religion as Cultural Power: The Role of Religion in Influencing Americans' Symbolic Boundaries around Gender and Sexuality.” Sociology Compass 6(11): 870-882.

Valentino, Nicholas A. 1999. “Crime News and the Priming of Racial Attitudes During Evaluations of the President.” Public Opinion Quarterly 63(3):293-320.

Wald, Kenneth D., Dennis E. Owen, and Samuel S. Hill, Jr. 1988. "Churches as Political Communities.” American Political Science Review 82(2):531-548.

Whitehead, Andrew L., and Samuel L. Perry 2015. “A More Perfect Union? Christian Nationalism and Support for Same-Sex Unions." Sociological Perspectives 58(3):422440. 
Wildeman, Christopher. 2010. "Parental Incarceration and Children's Physically Aggressive Behaviors: Evidence from the Fragile Families and Wellbeing Study.” Social Forces 89(1):285-309.

Williams, Kristi, Sharon Sassler, Adrianne Frech, Fenaba Addo, and Elizabeth Cooksey. 2011. “Nonmarital Childbearing, Union History, and Women's Health at Midlife." American Sociological Review 76(3):465-86. 


\section{Figures and Tables}

Figure 1: Predicted Support for Same-Sex Marriage, Adoption, and Sex by Number of Christian Books Read, Baylor Religion Survey

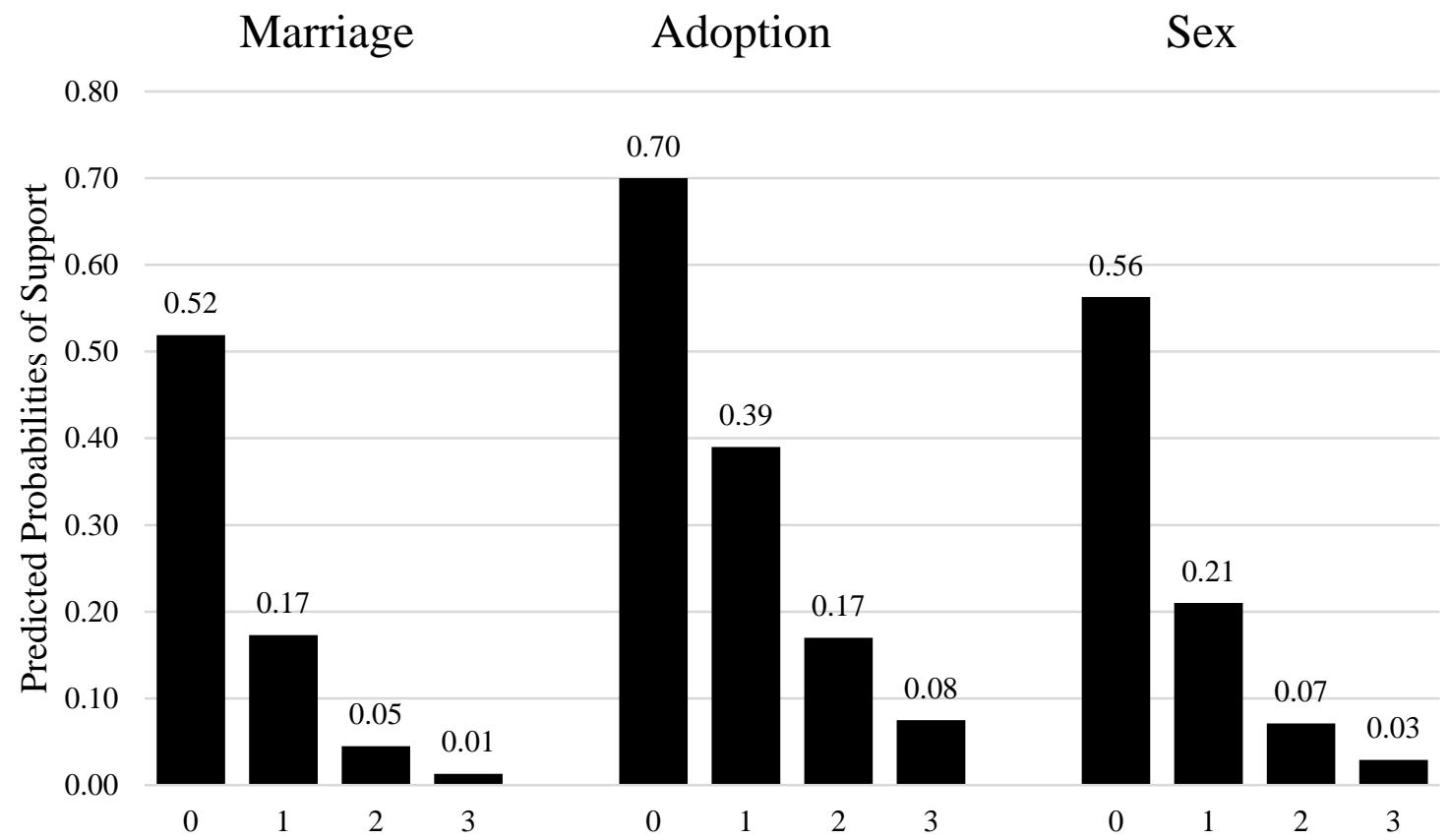

Source: Baylor Religion Survey, $2005(N=1,278)$

Note: The three books are The Purpose Driven Life, a book from the Left Behind series, and a James Dobson book. Comparisons between all categories and all other categories significantly different at $p<$ .001. These predicted probabilities are based upon multivariate logistic regression models presented in the online supplement that include religious practice (a scale of attendance, prayer, and scripture reading), whether evangelical, view of the Bible, age, gender, race, education, family income, parental status, marital status, region, and political affiliation. 
Figure 2: Predicted Support for Same-Sex Marriage, Adoption, and Sex by Number of Christian Shows Watched, Baylor Religion Survey

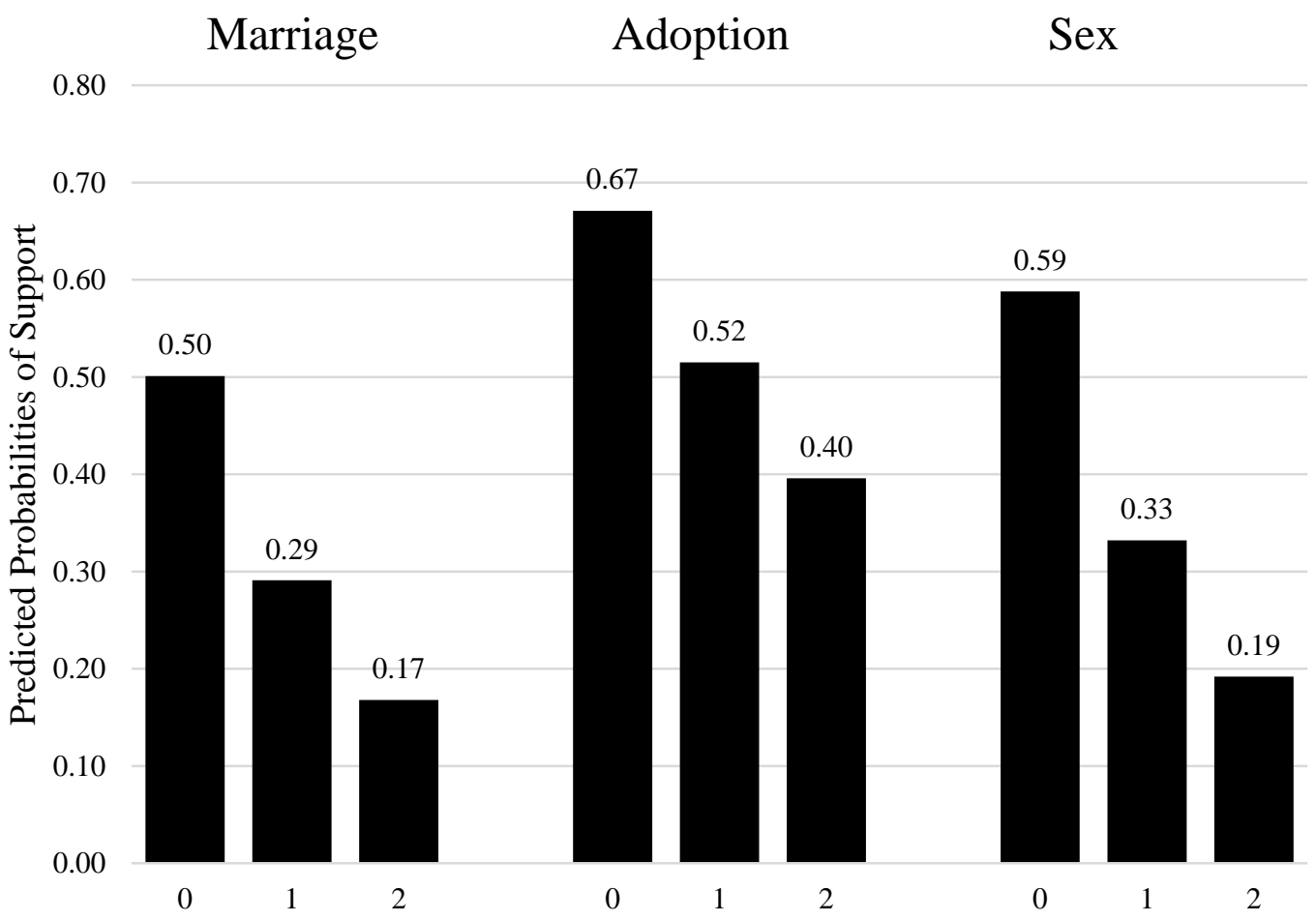

Source: Baylor Religion Survey, $2005(N=1,278)$

Note: The two shows are $7^{\text {th }}$ Heaven and Touched by an Angel. Comparisons between all categories and all other categories significantly different at $p<.001$. These predicted probabilities are based upon multivariate logistic regression models presented in the online supplement that include religious practice (a scale of attendance, prayer, and scripture reading), whether evangelical, view of the Bible, age, gender, race, education, family income, parental status, marital status, region, and political affiliation. 
Figure 3: Predicted Support for Same-Sex Marriage by Frequency of Religious Reading and Web Surfing, Portraits of American Life Study

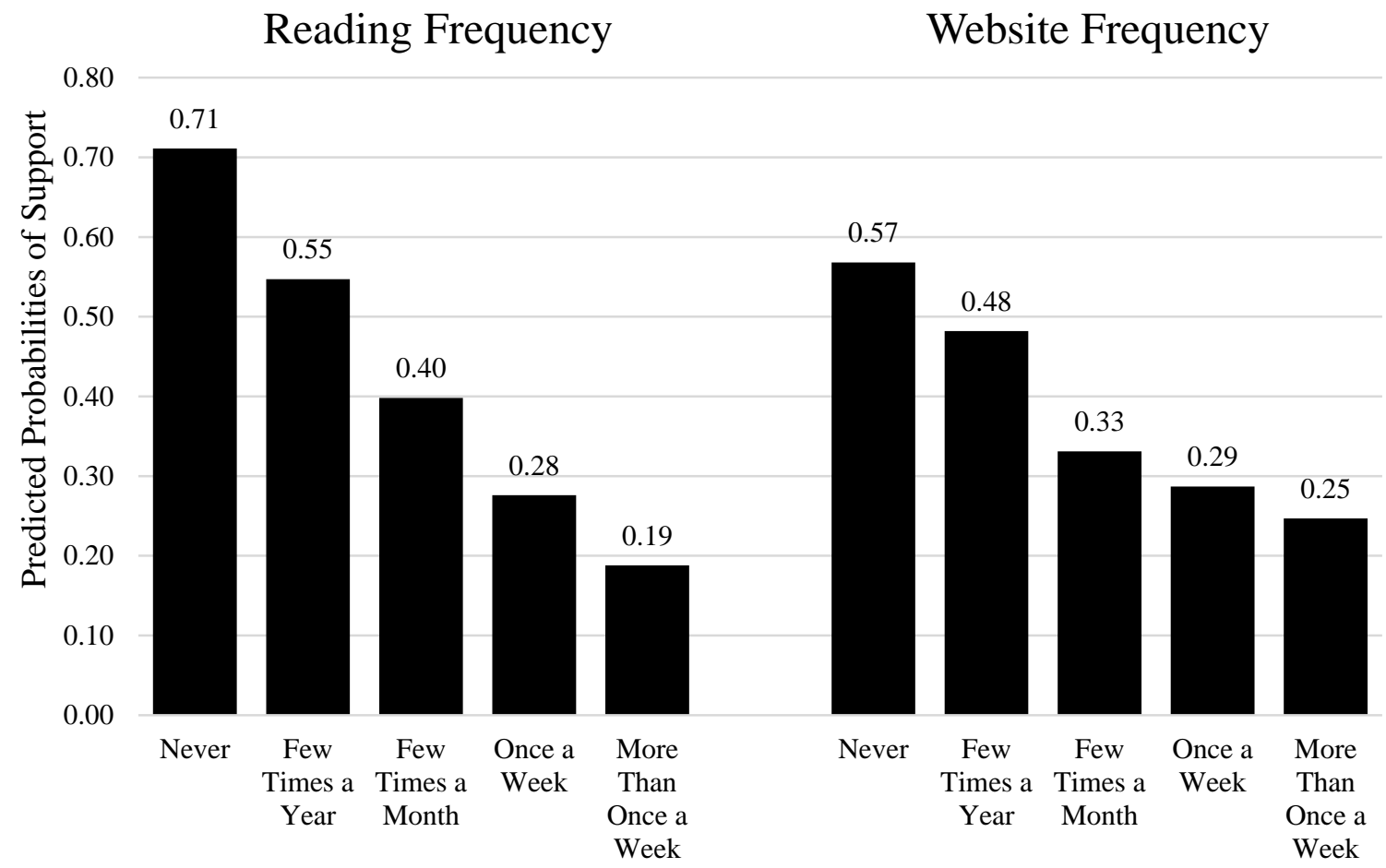

Source: Portraits of American Life Study, $2012(N=1,163)$

Note: Comparisons between all categories and all other categories significantly different at $p<.001$ for reading and $p<.05$ for websites. These predicted probabilities are based upon multivariate logistic regression models presented in the online supplement that include religious practice (a scale of attendance, prayer, and scripture reading), whether evangelical, view of the Bible, age, gender, race, education, family income, parental status, marital status, region, and political affiliation. 
Figure 4: Predicted Support for the Morality of Homosexuality by Time Spent Watching Religious Television, General Social Survey

\section{Time Spent Watching Religious Television}

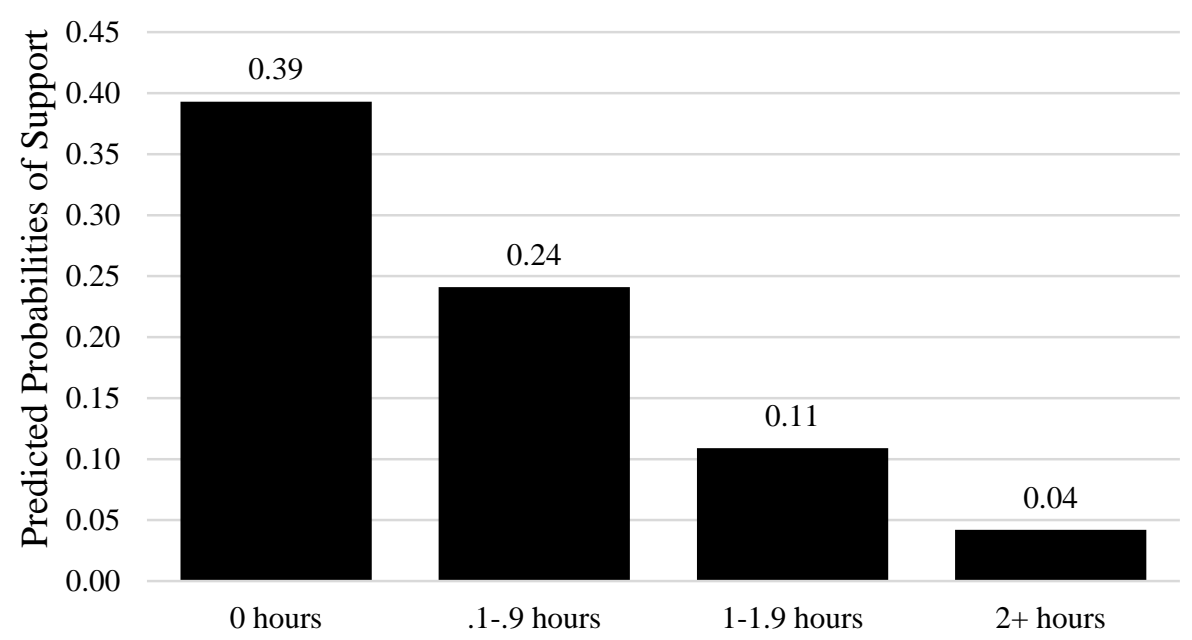

Source: General Social Survey, $1998(N=613)$

Note: Comparisons between all categories and all other categories significantly different at $p<.001$. These predicted probabilities are based upon multivariate logistic regression models presented in the online supplement that include religious practice (a scale of attendance, prayer, and scripture reading), whether evangelical, view of the Bible, age, gender, race, education, family income, parental status, marital status, region, and political affiliation. 
Table 1: Wording of Dependent Variables and Key Independent Variables

\begin{tabular}{|c|c|c|}
\hline Survey & Measure & Question Wording \\
\hline \multicolumn{3}{|l|}{ Dependent Variables } \\
\hline Baylor Religion Survey & Marriage & $\begin{array}{l}\text { How do you feel about the following marriage and family } \\
\text { related issues: Gay marriage. Always wrong, almost always } \\
\text { wrong, only wrong sometimes, or not wrong at all. }\end{array}$ \\
\hline Baylor Religion Survey & Adoption & $\begin{array}{l}\text { How do you feel about the following marriage and family } \\
\text { related issues: The adoption of a child by a gay couple. Always } \\
\text { wrong, almost always wrong, only wrong sometimes, or not } \\
\text { wrong at all. }\end{array}$ \\
\hline Baylor Religion Survey & Sex & $\begin{array}{l}\text { How do you feel about sexual relations in the following } \\
\text { circumstances: Between two adults of the same sex. Always } \\
\text { wrong, almost always wrong, only wrong sometimes, or not } \\
\text { wrong at all. }\end{array}$ \\
\hline Portraits of American Life Study & Marriage & $\begin{array}{l}\text { The only legal marriage should be a marriage between one man } \\
\text { and one woman. Strongly disagree, somewhat disagree, neither } \\
\text { agree nor disagree, somewhat agree, or strongly agree. }\end{array}$ \\
\hline General Social Survey & Sex & $\begin{array}{l}\text { What about sexual relations between two adults of the same } \\
\text { sex-do you think it is always wrong, almost always wrong, } \\
\text { wrong only sometimes, or not wrong at all? }\end{array}$ \\
\hline \multicolumn{3}{|l|}{ Key Independent Variables } \\
\hline Baylor Religion Survey & Reading & $\begin{array}{l}\text { Have you read any of the following books: (1) The Purpose } \\
\text { Driven Life. (2) Any book by James Dobson (Focus on the } \\
\text { Family). (3) Any book in the Left Behind Series. }\end{array}$ \\
\hline Baylor Religion Survey & Watching & $\begin{array}{l}\text { Have you seen any of the following movies/television shows: (1) } \\
7^{\text {th }} \text { Heaven. (2) Touched by an Angel. }\end{array}$ \\
\hline Portraits of American Life Study & Reading & $\begin{array}{l}\text { In the past } 12 \text { months, how often have you read religious books, } \\
\text { newspapers or magazines? Never, a few times a year, one to } \\
\text { three times a month, once a week, more than once a week. }\end{array}$ \\
\hline Portraits of American Life Study & Websites & $\begin{array}{l}\text { In the past } 12 \text { months, how often have you visited religious } \\
\text { websites or participated in religious groups on the Internet? } \\
\text { Never, a few times a year, one to three times a month, once a } \\
\text { week, more than once a week. }\end{array}$ \\
\hline General Social Survey & Watching & $\begin{array}{l}\text { About how much time per week, in hours and minutes, do you } \\
\text { normally spend watching religious shows on television? }\end{array}$ \\
\hline
\end{tabular}


Table 2: Descriptive Statistics

\begin{tabular}{|c|c|c|c|c|c|c|c|c|c|c|}
\hline \multirow[b]{2}{*}{ Measures } & \multirow[b]{2}{*}{ Metric } & \multicolumn{3}{|c|}{$\begin{array}{l}\text { BRS }^{\mathrm{a}} \\
2005\end{array}$} & \multicolumn{3}{|c|}{$\begin{array}{l}\text { PALS }^{\mathrm{b}} \\
2012\end{array}$} & \multicolumn{3}{|c|}{$\begin{array}{l}\text { GSS }^{\mathrm{c}} \\
1998\end{array}$} \\
\hline & & Mean & SD & Range & Mean & SD & Range & Mean & SD & Range \\
\hline \multicolumn{11}{|l|}{ Dependent Variables } \\
\hline Accept Same-Sex Marriage & $\begin{array}{l}\text { Not Wrong at All and Only Wrong } \\
\text { Sometimes }=1\end{array}$ & .40 & & & & & & & & \\
\hline Accept Same-Sex Marriage & $\begin{array}{l}\text { Strongly Disagree, Disagree, and Neither } \\
\text { Agree Nor Disagree That Legal Marriage } \\
\text { Should be Man/Woman }=1\end{array}$ & & & & .51 & & & & & \\
\hline Accept Same-Sex Adoption & $\begin{array}{l}\text { Not Wrong at All and Only Wrong } \\
\text { Sometimes=1 }\end{array}$ & .52 & & & & & & & & \\
\hline Accept Same-Sex Sex & $\begin{array}{l}\text { Not Wrong at All and Only Wrong } \\
\text { Sometimes }=1\end{array}$ & .42 & & & & & & .35 & & \\
\hline \multicolumn{11}{|l|}{ Independent Variables } \\
\hline Christian Reading & $\begin{array}{l}\text { Sum of Books Read (The Purpose Driven Life, } \\
\text { a Left Behind Series Book, and a Book By } \\
\text { James Dobson) }\end{array}$ & .60 & .930 & $0-3$ & & & & & & \\
\hline Christian TV Watching & $\begin{array}{l}\text { Sum of Shows Watched ( } 7^{\text {th }} \text { Heaven and } \\
\text { Touched By an Angel) }\end{array}$ & .97 & .84 & $0-2$ & & & & & & \\
\hline Religious Reading Frequency & Never $=1$, More Than Weekly $=5$ & & & & 2.30 & 1.31 & $1-5$ & & & \\
\hline Religious Websites Frequency & Never $=1$, More Than Weekly $=5$ & & & & 1.51 & .98 & $1-5$ & & & \\
\hline Religious TV Time & Hours Spent Watching Religious TV Per Week & & & & & & & .45 & .91 & $0-7$ \\
\hline \multicolumn{11}{|l|}{ Religion Controls } \\
\hline Practice Scale & $\begin{array}{l}\text { Summated Scale of Standardized Frequencies } \\
\text { of Religious Service Attendance, Prayer, and } \\
\text { Scripture Reading }\end{array}$ & .00 & .96 & $\begin{array}{c}-1.35- \\
1.44\end{array}$ & .00 & .86 & $\begin{array}{l}-1.21- \\
1.75\end{array}$ & .00 & .82 & $\begin{array}{l}-1.40- \\
1.70\end{array}$ \\
\hline Evangelical & Evangelical $=1$ & .29 & & & .23 & & & .29 & & \\
\hline Bible Ancient Book (ref.) & Bible is an Ancient Book=1 & .25 & & & & & & & & \\
\hline Some Human Error & Bible Contains Some Human Error=1 & .13 & & & & & & & & \\
\hline True, Not Literal & Bible True, Not Literal=1 & .39 & & & & & & & & \\
\hline Bible Literal & Bible Literal $=1$ & .18 & & & & & & & & \\
\hline Unsure & I Don't Know=1 & .06 & & & & & & & & \\
\hline Bible Not Inspired (ref.) & Bible Not Inspired $=1$ & & & & .10 & & & & & \\
\hline Bible Partly Inspired & Bible Partly Inspired $=1$ & & & & .32 & & & & & \\
\hline Bible Fully Inspired & Bible Fully Inspired=1 & & & & .59 & & & & & \\
\hline Bible Ancient Book (ref.) & Bible is an Ancient Book $=1$ & & & & & & & .13 & & \\
\hline Bible Inspired & Bible is Inspired Word of God $=1$ & & & & & & & .54 & & \\
\hline Bible Literal & Bible is Literal Word of God=1 & & & & & & & .34 & & \\
\hline
\end{tabular}

${ }^{a}$ Baylor Religion Survey $(2005 ; N=1,278)$

b Portraits of American Life Study (2012; $N=1,163)$

c General Social Survey $(1998 ; N=613)$ 
Religious Media and Same-Sex Relationships

Table A1: Correlation Matrix of Focal Variables in Baylor Religious Survey Analyses $(N=1,278)$

\begin{tabular}{|c|c|c|c|c|c|c|c|}
\hline & (1) & $(2)$ & (3) & (4) & $(5)$ & (6) & (7) \\
\hline (1) Accept Same-Sex Marriage & 1 & & & & & & \\
\hline (2) Accept Same-Sex Adoption & $0.728^{* * *}$ & 1 & & & & & \\
\hline (3) Accept Same-Sex Sex & $0.794^{* * *}$ & $0.686^{* * *}$ & 1 & & & & \\
\hline (4) Christian Reading & $-0.334^{* * *}$ & $-0.331^{* * *}$ & $-0.333^{* * *}$ & 1 & & & \\
\hline (5) Christian TV Watching & $-0.199^{* * *}$ & $-0.154^{* * *}$ & $-0.230^{* * *}$ & $0.298^{* * *}$ & 1 & & \\
\hline (6) Religious Practice & $-0.432^{* * *}$ & $-0.419^{* * *}$ & $-0.481^{* * *}$ & $0.525^{* * *}$ & $0.264^{* * *}$ & 1 & \\
\hline (7) Evangelical & $-0.328^{* * *}$ & $-0.368^{* * *}$ & $-0.331^{* * *}$ & $0.381^{* * *}$ & $0.196^{* * *}$ & $0.362^{* * *}$ & 1 \\
\hline (8) Bible Ancient Book & $0.461^{* * *}$ & $0.402^{* * *}$ & $0.492^{* * *}$ & $-0.279^{* * *}$ & $-0.265^{* * *}$ & $-0.509^{* * *}$ & $-0.273^{* * *}$ \\
\hline (9) Some Human Error & $0.119^{* * *}$ & $0.118^{* * *}$ & $0.136^{* * *}$ & $-0.100^{* * *}$ & -0.033 & $-0.049^{+}$ & $-0.117^{* * *}$ \\
\hline (10) True, Not Literal & $-0.235^{* * *}$ & $-0.157^{* * *}$ & $-0.269^{* * *}$ & $0.108^{* * *}$ & $0.148^{* * *}$ & $0.250^{* * *}$ & $0.057^{*}$ \\
\hline (11) Bible Literal & $-0.347^{* * *}$ & $-0.369^{* * *}$ & $-0.351^{* * *}$ & $0.329^{* * *}$ & $0.168^{* * *}$ & $0.395^{* * *}$ & $0.377^{* * *}$ \\
\hline (12) Unsure & 0.034 & 0.018 & 0.031 & $-0.106^{* * *}$ & -0.045 & $-0.156^{* * *}$ & $-0.066^{*}$ \\
\hline
\end{tabular}

Source: Baylor Religion Survey 2005

${ }^{+} p<0.10,{ }^{*} p<0.05,{ }^{* *} p<0.01,{ }^{* * *} p<0.001$ (two-tailed) 
Table A2: Correlation Matrix of Focal Variables in Portraits of American Life Study Analyses $(N=$ 1,163)

\begin{tabular}{|c|c|c|c|c|c|}
\hline & (1) & (2) & (3) & (4) & $(5)$ \\
\hline (1) Accept Same-Sex Marriage & 1 & & & & \\
\hline (2) Religious Reading Frequency & $-0.304^{* * *}$ & 1 & & & \\
\hline (3) Religious Websites Frequency & $-0.147^{* * *}$ & $0.465^{* * *}$ & 1 & & \\
\hline (4) Religious Practice & $-0.310^{* * *}$ & $0.664^{* * *}$ & $0.435^{* * *}$ & 1 & \\
\hline (5) Evangelical & $-0.240^{* * *}$ & $0.170^{* * *}$ & $0.144^{* * * *}$ & $0.210^{* * *}$ & 1 \\
\hline (6) Bible Not Inspired & $0.227^{* * *}$ & $-0.188^{* * *}$ & $-0.084^{* *}$ & $-0.333^{* * *}$ & $-0.146^{* * *}$ \\
\hline (7) Bible Partly Inspired & $0.237^{* * *}$ & $-0.277^{* * *}$ & $-0.165^{* * *}$ & $-0.349^{* * *}$ & $-0.174^{* * *}$ \\
\hline (8) Bible Fully Inspired & $-0.361^{* * *}$ & $0.375^{* * *}$ & $0.206^{* * *}$ & $0.530^{* * *}$ & $0.252^{* * *}$ \\
\hline
\end{tabular}

Source: Portraits of American Life Study 2012

${ }^{+} p<0.10,{ }^{*} p<0.05,{ }^{* *} p<0.01,{ }^{* * *} p<0.001$ (two-tailed) 
Table A3: Correlation Matrix of Focal Variables in General Social Survey Analyses $(N=613)$

\begin{tabular}{|c|c|c|c|c|}
\hline & (1) & (2) & (3) & (4) \\
\hline (1) Accept Same-Sex Sex & 1 & & & \\
\hline (2) Hours of Religious TV Per Week & $-0.218^{* * *}$ & 1 & & \\
\hline (3) Religious Practice & $-0.328^{* * *}$ & $0.315^{* * *}$ & 1 & \\
\hline (4) Evangelical & $-0.233^{* * *}$ & 0.065 & $0.206^{* * *}$ & 1 \\
\hline (5) Bible Ancient Book & $0.214^{* * *}$ & $-0.130^{* *}$ & $-0.298^{* * *}$ & $-0.156^{* * *}$ \\
\hline (6) Bible Inspired & $0.175^{* * *}$ & $-0.104^{* *}$ & $-0.144^{* * *}$ & $-0.119^{* *}$ \\
\hline (7) Bible Literal & $-0.334^{* * *}$ & $0.201^{* * *}$ & $0.361^{* * *}$ & $0.235^{* * *}$ \\
\hline
\end{tabular}

Source: General Social Survey 1998

${ }^{+} p<0.10,{ }^{*} p<0.05,{ }^{* *} p<0.01,{ }^{* * *} p<0.001$ (two-tailed) 